\title{
The Impact of Adequate Working Conditions for Older Employees on Work Engagement of Older Employees in Financial Services Companies
}

\author{
Maja Rožman*, Vesna Čančer \\ Faculty of Economics and Business, University of Maribor, Slovenia
}

Received July 31, 2019; Revised September 9, 2019; Accepted September 19, 2019

Copyright@2019 by authors, all rights reserved. Authors agree that this article remains permanently open access under the terms of the Creative Commons Attribution License 4.0 International License

\begin{abstract}
The main objective of the paper is to determine the impact of adequate working conditions for older employees on work engagement of older employees in financial services companies in Slovenia. The research is based on the implementation of a factor analysis by which we wanted to reduce the large number of variables into a smaller number of factors. With those factors, we performed a regression analysis. Based on the results, we confirmed the hypothesis that adequate working conditions for older employees have a significant positive impact on work engagement of older employees in financial services companies in Slovenia. From this point of view, financial services companies should apply appropriate measures to reduce workload as well as to contribute to employees' well-being and better workplace performance, which is reflected in work engagement of older employees.
\end{abstract}

Keywords Older Employees, Adequate Working Conditions, Work Engagement, Factors Analysis, Regression Analysis

\section{Introduction}

The aging of the European population is a demographic trend that is expected to continue in the coming decades, and is reflected in the ever growing number of older employees (Principi et al., 2015). As the workforce is aging and becoming increasingly age diverse, successful aging at work has been proclaimed to be a desirable process and outcome, as well as a responsibility of both employees and their companies (Zacher and Rudolph, 2017). Therefore, ageing of the workforce presents a big challenge to all companies which differ by sectors. One of the ways with which companies can prove that they value and appreciate older employees is by implementing human resources policies and practices intended to deal with the needs and improvement of work conditions for older employees (Vasconcelos, 2015). Effectively managing workforce diversity is an issue that financial executives generally are addressing with increasing frequency (Zacher and Rudolph, 2017). Companies will have to look for new and better ways of management of older employees (Baltzell, 2000) and achieve greater engagement at work, better performance and well-being of older employees at work (Moyers and Coleman, 2004), especially in financial services companies (Frith, 2017). According to Frith (2017), financial services companies are placed under the most stressful job. Indeed, it is becoming critical to understand how to design jobs to keep employees of different ages engaged in their work (Truxillo et al., 2012). Zaniboni et al. (2014) found out that relationship between certain job characteristics and job attitudes may differ across the life span. The creation of a unified approach to diversity and inclusion, which is embedded in the business ethics of the company, can have a sustainable positive impact on the health and well-being of individuals, business and society (Sanyal et al., 2015).

Older employees present an increasingly important source of labour for companies. Irrespective of age, an employee needs the appropriate skills and knowledge to be productive and to help the company achieve its strategic objectives. However, in many companies, older employees are less likely to be offered training opportunities than their younger compatriots. A person is able to learn at any age and the older employee is capable of adjusting to changes in work. Many people assume that older employees are homogeneous but this is not the case. There are significant differences between older employees and these differences need to be acknowledged and understood (Davies et al., 2017). Training is an important component of retention and 
increasing the availability of training is critical for retaining older employees. However, it is well documented that employers have been largely remissed in providing training for older employees. Thus, older employees are less likely to be offered training opportunities and to participate in training (Armstrong-Stassen and Templer, 2005).

Fuertes et al. (2013) summarize that companies should consider age appropriate job design, ensure that employees are kept flexible, support lifelong learning and better enable the intergenerational transfer of knowledge. The demographics of the global workforce are changing, specifically with a more age diverse workforce bringing new research questions. It becomes more important to find ways for people to stay satisfied and engaged in their work at different life stages (Zaniboni et al., 2014). Research has shown that job characteristics can lead both positive and negative work outcomes (e.g. Slattery et al., 2010). For example, the research showed that task variety was related to positive outcomes like job satisfaction but also to negative outcomes like job overload (Humphrey et al., 2007). Based on research, authors Rumbles and Rees (2013) summarize that managers are aware that employees are experiencing high stress, but managers do not do anything to alleviate employee stress. According to Rune and Stener (2006) there is high stress level in financial services. Therefore, companies, especially financial services companies should be aware of the importance of reducing the workload of their employees.

The first step towards the adequate management of older employees is to create an appropriate working environment that dictates the successful result of ageing for employees and thus the achievement of goals, performance and competitiveness of the company. The main objective of this article is to establish the impact of an adequate working condition for older employees on work engagement of older employees in financial services companies in Slovenia. Our research is the first research in Slovenia that analyses the impact of adequate working conditions for older employees on work engagement of older employees in financial services companies. There is not much literature and research that is comprehensively and systematically based on theoretical knowledge nor studies about older employees and their work engagement in financial services companies. With this research we wanted to fill that gap. The research is based on the application of a factor analysis to reduce the large number of variables to a smaller number of factors with which we conducted a simple regression and multiple regression analysis.

In the following sections, we firstly present the review of the literature. It is followed by a description of methodology used in our empirical research and the obtained results. The article concludes with the discussion of the main findings, limitations and further research possibilities.

\section{Literature Review}

\subsection{Conceptualizing Age}

The term "older worker" has been used to refer to workers from the age of 40 to those aged over 75 depending on the purpose and field of study (Tew, 2004; Warr and Fay, 2001). In studies concerning labor market participation, the term "older worker" usually refers to workers aged 50 or 55 and above (Kooij et al., 2008). Zacher and Rudolph (2015) state that as age is a continuous variable, no cut-off exists when a worker becomes an »older worker «, but, for practical reasons, organizations and governments often use cut-offs such as 40,45 , or 50 years.

Aging refers to changes that occur in biological, psychological, and social functioning over time and, therefore, affects each individual on the personal, organizational, and societal levels (Lange et al., 2006). Kooij et al. (2008) summarize that individuals with the same chronological age may differ in terms of health, career stage, and family status. Chronological or calendar age may serve as a proxy for age-related processes that can influence work outcomes directly or indirectly and, therefore, cannot be captured within one single definition or conceptualization.

\subsection{Older Employees}

The nature of the work itself may serve to encourage employees to either leave or remain in employment. Work which is overly physically or mentally demanding may lead employees to leave, at the same time, a job which lacks variety of challenges may also provide little incentive to remain in work (Principi et al., 2015). Existing evidence has suggested that there is high demand for more flexible work among older employees which may help employees to better manage the demands of their work as they age (Dworschak et al., 2006). Older employees face a lack of support and negative stereotyping in the workplace in financial services companies (see, e.g. Kooij et al., 2008; Frith, 2017).Wade (2003) explains that discrimination against the older people has been a big problem for a long time. Spencer (2018) summarizes that age discrimination is explicitly reflected in financial services companies. Wade (2003) emphasizes that there are many positive things which companies should know about older employees, but unfortunately are not informed about, and there are many things which should be done and changed for a better working environment for the older workers, but unfortunately they have not been implemented yet.

Financial services companies must find ways to retain older employees while embracing a multi-generational workforce. Older employees can provide extensive value in the workplace due to their decades-long experience, worth ethic and stability. For example, without this 
generation of employees, companies could risk losing potential customers who prefer speaking to older, "more experienced" employees about financial matters (Spencer, 2018).

Older employees will become increasingly crucial for the retention of competitive advantage on labour market (AARP, 2005). They present the educated, reliable, experienced and stable workforce (Kooij et al., 2008). Their advantages are also greater reliability, stability, honesty, trust, loyalty and dedication to their work (Chasteen et al., 2002).

\subsection{Creating Suitable Working Conditions for Older Employees}

Many older employees are more likely to carry on working if there is flexibility of working arrangements, such as the opportunity to work from home, working part-time and flexible working hours. Flexible working policies are found to bring several benefits for employees. Unfortunately, older employees often face negative attitudes in the labour market - from employers, colleagues or from the in-work. It is likely that employers' negative attitudes have a direct impact on their intentions to hire someone older or to allow workplace adjustments or access to training to facilitate older employee to carry on working (Koc-Menard, 2009). Therefore, employers have to be aware of the importance of management of older employees and new approaches in the field of human resources management which enable older employees a friendly working environment (Albrecht, 2001) and well-being in the workplace (Haymes, 2013). According to Frith (2017) financial services companies are renowned for being a particularly stressful job. Also, the financial services sector has the highest percentage of employee absences due to mental ill health. Frith (2017) summarizes that analysis of AdviserPlus' records of more than a quarter of a million employees shows that since 2013 33.9\% of absence days in the financial services sector have been due to mental ill health. This compares to $24 \%$ of absence days in the retail sector and $22 \%$ in utilities. Therefore, financial services companies should create suitable working conditions for older employees.

Ilmarinen (2006) states that employers affect the successful ageing of all employees with adequate workplaces which include adequate solutions and measures. Employers have to ensure adequate flexibility at work and establish an appropriate working environment for older employees. The emphasis should be directed to decreasing workload in workplaces. According to OECD (2006), older employees have a higher interest in working time flexibility than younger employees because they frequently have to care for their elderly parents or need time for regeneration. Dworschak et al. (2006) emphasise that organisations have to ensure age appropriate forming of workplaces and a flexible workday, support for lifelong learning and an intergenerational transfer of knowledge for older employees. The objectives of management of older employees have to be in harmony with the strategic priorities in connection with human resources planning (Ilmarinen, 2006, Fraccaroli et al., 2017).

To have employees of all ages satisfied and engaged at work, we need to understand which working conditions are the best for them. Indeed, some characteristics may have more beneficial effects in younger employees but less in older employees (e.g. task variety). For example, it may be important for employers to challenge younger employees with different tasks, in particular during the organizational socialization phase when they are learning their jobs. In contrast, providing more tasks may actually be detrimental to older employees. Furthermore, considering the aging working population, it is important for organizations to develop jobs that enable people to continue to work successfully. It seems that older employees may not benefit from simply doing more tasks, but rather from opportunities to use their wide range of accumulated skills (Zaniboni et al., 2013).

Human resources management programs create opportunities for older employees to use their skills, avoiding (or reducing) requirements to perform more tasks, which may be helpful in keeping older employees satisfied and engaged at work. For example, it may be a competitive gain for organizations to utilize the experience and competencies of older workers, and to promote the transfer of knowledge and skills to younger colleagues (e.g. mentoring and coaching programs), by having younger employees perform a wide range of tasks (Zaniboni et al., 2014). Therefore, in order to design and implement efficient and effective age-differentiated interventions, it is necessary to gain a better knowledge of differences between workers of different age.

Magnavita (2017) emphasizes that older employees need flexible work arrangements and ergonomic changes in the working environment to facilitate their prolonged working lives. However, even in more developed countries, less than one-third of companies offer some form of flexible working arrangement, due to concerns about costs, productivity, and fairness. European governments should promote such workplace policies, so that employers see the profitable results of flexible arrangements for older employees. Furthermore, they should support educational efforts aimed at changing ageist attitudes.

Better health and life expectancy of older employees improve their opportunities to enhance an age-friendly society. However, a good working life is an important prerequisite for older employees to remain active and ensure that society benefits from their strengths and talents. In doing so, they participate actively in building up a sustainable and caring society, where solidarity exists between the generations and productive working life is an important platform for active ageing. Satisfactory employment can help people avoid sickness and physical or mental deterioration, secure good cognitive and physical capacity, and promote positive and active attitudes towards 
life. The quality of working life has a big impact on all workers, because we spend so much of our time at work. Therefore, investments in active ageing need to be secured during the working years. The investments in occupational health and safety in workplaces are also investments for the rest of our lives (Ilmarinen, 2012).

\subsection{Work Engagement of Older Employees}

The aging of population and the growth of older employees' percentage in organizations are interrelated with the integration of older employees at the labor market (Bejtkovský, 2016). Thus, from the human resource management perspective, it is important to understand the factors facilitating work engagement of older employees. Older employees continue working if they are successfully convinced to remain with the organization. Meanwhile, early retirement is seen as the outcome of poor work engagement. Notably, work engagement of older employees is determined by the factors related to employee, work and organization (Korsakienè et al., 2017).

Banihani et al. (2013) claim that work engagement has positive consequences for employees and companies. The benefits of being engaged range from positive emotional outcomes to improving organisational performance. Banihani et al. (2013) summarize that at the individual level, engaged employees perform better than non-engaged employees from the following four reasons: (1) engaged employees experience positive emotions such as happiness, enthusiasm, and joys; (2) they have better health; (3) they are able to create their own job and personal resources and (4) they often transfer their engagement to others. Moreover, work engagement influences the well-being and performance of employees. Also, lack of employee engagement may ruin a company's productivity. Sadly, many leaders still can't keep their employees engaged (see, e.g. Lu et al., 2016; Bakker and Demerouti, 2009).

Based on the literature review, we formulated a hypothesis H1: Adequate working conditions for older employees have a significant positive impact on work engagement of older employees in financial services companies in Slovenia.

\section{Methodology}

\subsection{Data and Sample}

We gathered the data with quantitative research on the final sample. In the first step we first defined the population of companies, which presented the basis for acquisition of units in the final sample. We limited our research to medium and large financial services companies in Slovenia. Based on the assumption, many companies with a smaller number of employees have not developed systematic human resources management. The assumption stated above is based on the results of the research study of
Hornsby and Kuratko (2003): they suggest that the majority of small companies do not have a human resources professional and that the owner of a small company performs this function; authors also state that the percentage of companies that have a human resources department grows with the size of the company. Based on random selection we included 1.000 companies of all industries, but in this research we limited on financial services companies. Data collecting was performed with the method of electronic and written questioning. We asked the employer to distribute a questionnaire among older employees - up to 3 employees (as there are different theoretical principles, we decided to use 50 years old as the boundary for employees).

The main survey involved 237 large- and medium-sized financial services companies. Thus, 704 older employees and 237 employers responded to the questionnaire.

The structure of employers was as follows:

- $\quad$ Regarding the achieved education level of employers who participated in the research, $49.8 \%$ of the respondents have high professional or university degree, $31.3 \%$ of them have a master's degree or doctorate, $18.1 \%$ of them finished college, and the smallest percentage presents the respondents with finished vocational or high school (0.8\%).

- According to the length of service of the respondents, $54.4 \%$ of respondents with the length of service from 31 to 40 years were included in the research. In the second place were respondents with the length of service from 21 to 30 years $(41.3 \%)$. A low percentage present respondents with the length of service of more than 41 years (3\%) and respondents with the length of service from 11 to 20 years (1.3\%).

- The biggest share in the research presented large companies (56.5\%). Medium-sized companies comprised $43.5 \%$.

The structure of older employees was as follows:

- $\quad 44.7 \%$ of older employees involved in the survey aged from 56 to 61 years, $40.2 \%$ employees aged from 50 to 55 years and $14.7 \%$ employees aged from 62 to 67 years. The lowest percentage is presented by older employees aged over $68(0.4 \%)$ years.

- $\quad$ Regarding the achieved education level of employees who participated in the research, $37.5 \%$ of the respondents have high professional or university degree, $31.7 \%$ of them have a master's degree or doctorate, $24.4 \%$ of them finished college, and the smallest percentage presents the respondents with finished vocational or high school (6.4\%).

- According to the length of service of the respondents, $57.0 \%$ of older employees have the length of service from 31 to 40 years. In the second place were respondents with the length of service from 21 to 30 years (30.5\%). A low percentage of present 
respondents with the length of service of more than 41 years (12.5\%).

\subsection{Research Instrument}

As a research instrument we used a survey questionnaire with which we gained the width of insight in the field in question. The questionnaire includes questions of a closed type. The respondents indicated on a 5-point Likert-type scale their agreement to the listed statements, where $1=$ strongly disagree and $5=$ completely agree ( 1 -I completely disagree, $2-$ I do not agree, $3-$ I partially agree, $4-$ I agree, 5 -I completely agree).

Table 1 shows the statements of several authors that we included in our questionnaire.

Table 1. Statements of several authors in the Questionnaire

\begin{tabular}{|c|c|c|}
\hline Dimension & Items & Source \\
\hline \multirow[b]{3}{*}{$\begin{array}{l}\text { Adequate } \\
\text { conditions for older } \\
\text { employees }\end{array}$} & $\begin{array}{l}\text { Q1a: In the company we take care for reduction of workload of an older } \\
\text { employee in the workplace by work transformation. }\end{array}$ & Beck (2013) \\
\hline & $\begin{array}{l}\text { Q1b: Obligation for management of older employees on all levels of the } \\
\text { company prevails in the company. } \\
\text { Q1c: In the company we encourage changes in connection with older } \\
\text { employees. } \\
\text { Q1d: We take care for the improvement of working conditions for older } \\
\text { employees. }\end{array}$ & Ilmarinen (2006) \\
\hline & $\begin{array}{l}\text { Q1e: We enable older employees a condensed workday (meaning } \\
\text { performance of full number of hours, but within a tight period). } \\
\text { Q1f: We offer older employees work flexible benefits (e.g. additional free } \\
\text { days). } \\
\text { Q1g: We offer older employees the choice of workspace (work from home or } \\
\text { from a remote location). } \\
\text { Q1h: We offer older employees a flexible workday (we leave it to the } \\
\text { employees to choose for themselves within the given frames the time for start } \\
\text { and end of work). } \\
\text { Q1i: We enable older employees to job share (two or more employees share } \\
\text { the tasks and responsibilities of one full-time post). } \\
\text { Q1j: We enable the implementation of programs for managing stress and } \\
\text { programs for well-being for older employees. } \\
\text { Q1k: Older employees have the chance of group self-rostering to work. } \\
\text { Q1l: We enable older employees' variable working hours (similar to a } \\
\text { flexible workday, only that in this case there is no main workday or defined } \\
\text { number of hours that need to be performed in a report period). } \\
\text { Q1m: Older employees have the chance to go from a full-time workday to a } \\
\text { shorter workday (this form of work enables the employees to have more free } \\
\text { time instead of higher income. } \\
\text { Q1n: In the company we enable introduction of mentoring. } \\
\text { Q10: In the company we integrate older employees in strategy planning and } \\
\text { initiatives for management of older employees. } \\
\text { Q1p: In the company age diversity has to be connected with the company } \\
\text { strategy for equality and diversity. } \\
\text { Q1r: In the whole company there is communication and informing on the } \\
\text { management of older employees. } \\
\text { Q1s: We organize education and training programs which are specifically } \\
\text { tailored for older employees. }\end{array}$ & $\begin{array}{l}\text { Dworschak et al. (2006), } \\
\text { Ilmarinen, (2006), Naegele } \\
\text { and Walker (2006), } \\
\text { Brown (2005) }\end{array}$ \\
\hline \multirow{5}{*}{ Work engagement } & $\begin{array}{l}\text { Q2a: I perform/do my work with passion. } \\
\text { Q2b: I am engaged to the quality of my work. } \\
\text { Q2d: I feel connection with the company in which I worked. } \\
\text { Q2e: I am aware of the importance of innovation for our company and I am } \\
\text { helping to develop the company. } \\
\text { Q2g: I feel that my work and job are important. } \\
\text { Q2h: I am proud to be employed in this company. }\end{array}$ & Macey and Schneider (2008) \\
\hline & Q2c: I am engaged to achieving successful business results. & Wagner and Harter (2006) \\
\hline & Q2f: I trust in my colleagues and the manager. & Gruman and Saks (2011) \\
\hline & Q2i: I believe in the successful development and operation of our company. & Xu and Thomas (2011) \\
\hline & $\begin{array}{l}\text { Q2j: I would not leave the company, even if I could offer another job } \\
\text { opportunity. } \\
\text { Q2k: I feel very good at my workplace. } \\
\text { Q2l: I feel like a "part of the family" in the company. }\end{array}$ & Robertson and Cooper (2010) \\
\hline
\end{tabular}




\subsection{Statistical Analysis}

Within the empirical part we wanted to establish if the use of a factor analysis is reasonable based on the Kaiser-Meyer-Olkin measure of sampling adequacy $(\mathrm{KMO} \geq 0.5)$ (Kaiser, 1974) and Bartlett's test of sphericity. We used a factor analysis to reduce a large number of variables into a fewer number of factors and to describe the factor with certain variables. To determine which variables best describe each factor, we considered the value of communalities and factor loadings. Costello and Osborne (2005) suggested that we eliminate those variables whose communalities were smaller than 0.40 . To get a clear factor structure, in the case of several factors, we eliminated those variables where factor loadings were greater than 0.40 on more than one factor (Field, 2013). In this way, we came to the final solution of formed factors with variables.

We used the rectangular rotation Varimax with the characteristic that the rotated factors are independent from each other (Manly, 2005). We saved the derived factor points and created new variables (factors).

Based on the gained new variables (factors) we performed a regression analysis. We checked the quality of the obtained regression model using correlation coefficient, determination coefficient, F-test, and t-test.

\section{Results}

\subsection{Results of Factor Analysis for Adequate Working Conditions for Older Employees in Financial Services Companies}

Value of Kaiser-Meyer-Olkin measure of sampling adequacy $(\mathrm{KMO}=0.919)$ and the results of Bartlett's test of sphericity (Approx. Chi-Square $=2705,872 ; d f=136 ; p$ $<0.001)$ suggested the use of factor analysis. In the initial result we got three factors. We successively eliminated the variables with factor loadings greater than 0.4 for two of three factors and after each step checked the clarity of the structure of factors. The order of variables elimination was the following: Q1g, Q1k, Q1m, Q1n and Q1e. That way we came to the final solution of formed factors with 13 variables (Table 2). Table 2 presents the results of factor analysis for the construct adequate working conditions for older employees.

Table 2. The final results of factor analysis for the construct adequate working conditions for older employees

\begin{tabular}{|c|c|c|c|}
\hline \multirow{2}{*}{ Statement } & \multirow{2}{*}{ Communalities } & \multicolumn{2}{|c|}{ Factor loadings } \\
\hline & & 1 & 2 \\
\hline $\begin{array}{l}\text { Q1a: In the company we take care for reduction of workload of an } \\
\text { older employee in the workplace by work transformation. }\end{array}$ & 0.815 & 0.846 & 0.314 \\
\hline $\begin{array}{l}\text { Q1b: Obligation for management of older employees on all levels of } \\
\text { the company prevails in the company. }\end{array}$ & 0.907 & 0.856 & 0.417 \\
\hline $\begin{array}{l}\text { Q1c: In the company we encourage changes in connection with } \\
\text { older employees. }\end{array}$ & 0.937 & 0.907 & 0.337 \\
\hline $\begin{array}{l}\text { Q1d: We take care for the improvement of working conditions for } \\
\text { older employees. }\end{array}$ & 0.876 & 0.829 & 0.435 \\
\hline $\begin{array}{l}\text { Q1f: We offer older employees work flexible benefits (e.g. } \\
\text { additional free days). }\end{array}$ & 0.652 & 0.728 & 0.348 \\
\hline $\begin{array}{l}\text { Q1h: We offer older employees a flexible workday (we leave it to } \\
\text { the employees to choose for themselves within the given frames the } \\
\text { time for start and end of work). }\end{array}$ & 0.871 & 0.372 & 0.856 \\
\hline $\begin{array}{l}\text { Q1i: We enable older employees to job share (two or more } \\
\text { employees share the tasks and responsibilities of one full-time post). }\end{array}$ & 0.827 & 0.151 & 0.897 \\
\hline $\begin{array}{l}\text { Q1j: We enable the implementation of programs for managing } \\
\text { stress and programs for well-being for older employees. }\end{array}$ & 0.628 & 0.642 & 0.381 \\
\hline $\begin{array}{l}\text { Q1l: We enable older employees variable working hours (similar to } \\
\text { a flexible workday, only that in this case there is no main workday } \\
\text { or defined number of hours that need to be performed in a report } \\
\text { period). }\end{array}$ & 0.682 & 0.381 & 0.732 \\
\hline $\begin{array}{l}\text { Q1o: In the company we integrate older employees in strategy } \\
\text { planning and initiatives for management of older employees. }\end{array}$ & 0.916 & 0.893 & 0.346 \\
\hline $\begin{array}{l}\text { Q1p: In the company age diversity has to be connected with the } \\
\text { company strategy for equality and diversity. }\end{array}$ & 0.936 & 0.859 & 0.445 \\
\hline $\begin{array}{l}\text { Q1r: In the whole company there is communication and informing } \\
\text { on the management of older employees }\end{array}$ & 0.926 & 0.893 & 0.359 \\
\hline $\begin{array}{l}\text { Q1s: We organize education and training programs which are } \\
\text { specifically tailored to older employees. }\end{array}$ & 0.622 & 0.619 & 0.489 \\
\hline \multicolumn{4}{|c|}{$\begin{array}{c}\text { Kaiser-Meyer-Olkin measure: } 0.908 \\
\text { Bartlett's Test of Sphericity: Approx. Chi-Square }=2136.915 ; d f=78 ; p<0.001\end{array}$} \\
\hline \multicolumn{4}{|c|}{$\begin{array}{l}\text { Cumulative percentage of explained variance (first factor): } 71.044 \% \\
\text { Cumulative percentage of explained variance (second factor): } 9.123 \%\end{array}$} \\
\hline
\end{tabular}


The values of the communalities for the adequate working conditions for older employees are higher than 0.60 (Table 2). In Table 2, it is visible that from 13 variables we got two factors which together explain $80.1 \%$ variability, namely: first factor $71.0 \%$, second factor $9.1 \%$.

We named both factors for construct of adequate working conditions for older employees regarding the variables that were included in each factor and present it, namely:

- Factor 1: Friendly working environment for older employees

- Factor 2: Suitable working conditions for older employees

The value of factor loadings presents the importance of each individual variable in a factor and higher the loadings, the more important the variable for the factor is. In our case, the most important role in friendly working environment for older employees (factor 1) is "In the company we encourage changes in connection with older employees." In suitable working conditions for older employees (factor 2) the most important factor is "We enable older employees to job share (two or more employees share the tasks and responsibilities of one full-time post).”

\subsection{Results of Factor Analysis for Work Engagement of Older Employees in Financial Services Companies}

Value of Kaiser-Meyer-Olkin measure of sampling adequacy $(\mathrm{KMO}=0.931)$ and results of Bartlett's test of sphericity (Approx. Chi-Square $=2605,356 ; d f=66 ; p<$ 0.001 ) suggest the use of factor analysis. Table 3 presents the results of factor analysis for the construct work engagement of older employees.

The values of all communalities in Table 3 for work engagement of older employees are higher than 0.80 , therefore we have not eliminated any variable. Table 3 also shows that total variance explained is $87.8 \%$. All factor loadings are higher than 0.90 . In our case, the most important role in work engagement of older employees is "I am engaged to the quality of my work."

\subsection{The Impact of Adequate Working Conditions for Older Employees on Work Engagement of Older Employees in Financial Services Companies}

In the continuation we present the results of testing of the hypothesis H1. Table 4 shows regression analysis results.

Table 3. The results of factor analysis for the construct work engagement of older employees

\begin{tabular}{|c|c|c|}
\hline Statement & Communalities & Factor loadings \\
\hline Q2a: I do my work with passion. & 0.911 & 0.954 \\
\hline Q2b: I am engaged to the quality of my work. & 0.914 & 0.959 \\
\hline Q2c: I am engaged to achieve successful business results. & 0.849 & 0.956 \\
\hline Q2d: I feel connection with the company in which I worked. & 0.897 & 0.952 \\
\hline $\begin{array}{l}\text { Q2e: I am aware of the importance of innovation for our company and I am helping to } \\
\text { develop the company. }\end{array}$ & 0.908 & 0.953 \\
\hline Q2f: I trust in my colleagues and the manager. & 0.867 & 0.931 \\
\hline Q2g: I feel that my work and job are important. & 0.888 & 0.942 \\
\hline Q2h: I am proud to be employed in this company. & 0.919 & 0.921 \\
\hline Q2i: I believe in the successful development and operation of our company. & 0.883 & 0.940 \\
\hline Q2j: I would not leave the company, even if I could get another opportunity for job. & 0.905 & 0.951 \\
\hline Q2k: I feel very good at my workplace. & 0.821 & 0.906 \\
\hline Q2l: I feel like a "part of the family" in the company. & 0.818 & 0.904 \\
\hline \multicolumn{3}{|c|}{$\begin{array}{l}\text { Kaiser-Meyer-Olkin measure: } 0.931 \\
\text { est of Sphericity: Approx. Chi-Square }=2605.356 ; d f=66 ; p<0.001\end{array}$} \\
\hline \multicolumn{3}{|c|}{ Cumulative percentage of explained variance: $87.765 \%$} \\
\hline
\end{tabular}


Table 4. Regression analysis results

\begin{tabular}{|c|c|c|c|c|c|c|}
\hline \multirow[b]{2}{*}{ Dependent variable } & \multirow[b]{2}{*}{ Independent variable } & \multicolumn{2}{|c|}{$\begin{array}{c}\text { Unstandardized } \\
\text { coefficients }\end{array}$} & \multirow{2}{*}{$\begin{array}{c}\text { Standardized } \\
\text { coefficients } \\
\text { Beta }\end{array}$} & \multirow[b]{2}{*}{$\mathbf{t}$} & \multirow[b]{2}{*}{ Signifi-cance } \\
\hline & & B & $\begin{array}{c}\begin{array}{c}\text { Standard } \\
\text { error }\end{array} \\
\end{array}$ & & & \\
\hline $\begin{array}{l}\text { Work engagement of } \\
\text { older employees }\end{array}$ & $\begin{array}{c}\text { Adequate working } \\
\text { conditions for older } \\
\text { employees - Factor 1: } \\
\text { Friendly working } \\
\text { environment for older } \\
\text { employees }\end{array}$ & 0.676 & 0.053 & 0.676 & 12.687 & 0.000 \\
\hline $\begin{array}{l}\text { Work engagement of } \\
\text { older employees }\end{array}$ & $\begin{array}{c}\text { Adequate working } \\
\text { conditions for older } \\
\text { employees - Factor 2: } \\
\text { Suitable working } \\
\text { conditions for older } \\
\text { employees }\end{array}$ & 0.475 & 0.053 & 0.475 & 8.907 & 0.000 \\
\hline
\end{tabular}

The value of the multiple correlation coefficient between dependent variable (work engagement of older employees) and independent variables (Factor 1: Friendly working environment for older employees 1 and Factor 2: Friendly working environment for older employees 2) for the hypothesis $\mathrm{H} 1$ is $r=0.826$ which indicates that there is a strong connection between the variables. The value of the adjusted determination coefficient is 0.676 . The adjusted determination coefficient explains that $67.6 \%$ of the variance of the dependent variable (work engagement of older employees) is explained with the variance of the independent variables (Factor 1: Friendly working environment for older employees 1 and Factor 2: Friendly working environment for older employees 2). We have established the reliability of the derived regression function with the F-test: $F=120.138, p<0.001$. The results of the regression (Table no. 4) indicated that the regression coefficient of Adequate working conditions for older employees - factor 1: Friendly working environment for older employees 1 was $0.676(\beta=0.676)$ and was significantly different from $0(p<0.001)$. The regression coefficient of adequate working conditions for older employees - factor 2: Friendly working environment for older employees 2 was $0.475(\beta=0.475)$ and was significantly different from $0(p<0.001)$. On the basis of conducted multiple regression analysis we confirmed the hypothesis: H1: Adequate working conditions for older employees have a significant positive impact on work engagement of older employees in financial services companies in Slovenia.

\section{Conclusions}

Based on the results we found that adequate working conditions for older employees have a significant positive impact on work engagement of older employees in financial services companies in Slovenia (Table 4). Results in Table 2 let us draw the conclusion that for adequate working conditions for older employees in financial services companies the following approaches play a big part: "In the company we encourage changes in connection with older employees" (factor 1: friendly working environment for older employees) and also, "We enable older employees to job share (two or more employees share the tasks and responsibilities of one full-time post)" (Factor 2: Suitable working conditions for older employees for older employees). Friendly working environment has an important effect on the health of older employees in financial services companies. Employees are healthier, feeling better, more motivated, satisfied and most importantly, they have greater enthusiasm for work in a friendly working environment. Therefore, it is important to encourage changes in connection with older employees. Also, poor health leads to early retirement or absenteeism therefore, adequate/suitable working conditions for older employees contribute to reducing the workload of older employees (for example, job share) and increasing work engagement.

Engaged employees are a vital prerequisite for a healthy company, because stressful and dissatisfied employees would not be able to deliver the same quality of work and productivity as those employees with lower stress levels and higher engagement. Therefore, it is important that employers create a safe and friendly work environment for older employees in financial services companies in Slovenia. The first step is to encourage changes in connection with older employees and create suitable working conditions for older employees. Also, the appropriate working condition with which financial services companies can reduce the workload of older employees is job-sharing. Job-sharing can be appealing for employees who are looking to reduce their hours. This tipe of flexible work can help employers retain experienced workers and reduce the workload.

The proportion of older employees will increase during the next few decades, therefore the new approaches to managing older employees are necessary. It becomes important to find ways for people to stay satisfied and engaged in their work at different life stages. The quality of 
working life has a big impact on employees because they spend so much of their time at work. Therefore, investments in active ageing need to be secured during the working years. In this regard, it is recommended to promote the quality of life and well-being of the population, especially older people, and to promote solidarity between the generations. According to Ilmarinen (2012) a good working life is an important platform to promote active ageing in companies. Therefore, occupational health and safety play a crucial role in securing active ageing through a better and longer work life.

Financial services companies should thus consider age appropriate job design, ensure adequate flexibility in work, support lifelong learning and better enable the intergenerational transfer of knowledge, for example mentoring. Recommendations for better managing older employees are also, redesign of the workplace (re-designing individual work tasks according to the needs and capabilities of employees) or job simplification, job rotation, redistribution in the company (coordinating job requirements with the capabilities and skills of employees) and more frequent short breaks at work. Also, companies should provide training for their older employees. Learning is not dependent on age but, instead, on the organization of learning. Therefore, special attention should be paid to the selection of learning strategies and environments suitable for ageing employees.

According to Eurofound (2015), poor working conditions have a negative impact on sustainable work outcomes for employees. Employees who are exposed to physical risks and quantitative demands (working at high speed and to tight deadlines) are more likely to experience worse health and poorer work-life balance. It is precisely at the age of 55 that participation in work strongly declines. Conditions of work such as good physical environment, lower quantitative demands and working time autonomy increase the likelihood of workers continuing working when they are aged 55 and over.

It is important to know that job characteristics are not experienced in the same way by all employees. From this perspective, our research shows the importance of friendly work environment for older employees in Slovenian companies, especially in financial services companies.

Our study is limited to the focus of older employees in Slovenia in medium-sized and large financial services companies. For further research we propose the examination of differences in working conditions for older employees and work engagement of older employees between different sectors. As an opportunity for future research, we see an upgrade of the measurement instrument with new constructs in the field of older employees. Also, our further research refers to analysing different constructs (for example, stress, job burnout and work engagement) with structural equation modelling (SEM).

\section{REFERENCES}

[1] AARP - American Association of Retired Persons, 2005. A business case for workers age 50+: Planning for tomorrow's talent needs in today's competitive environment. [online] Available at: <https://assets.aarp.org/rgcenter/econ/worker s_fifty_plus.pdf > [Accessed 11 February 2019].

[2] Albrecht, D. (2001). Getting ready for older workers. Workforce, 80(2), pp. 56-60.

[3] Armstrong-Stassen, M., Templer, A., 2005. Adapting training for older employees: The Canadian response to an aging workforce. Journal of Management Development, 24(1), pp.57-67.

[4] Bakker, A. B., Demerouti, E., 2009. The crossover of work engagement between working couples: a closer look at the role of empathy. Journal of Managerial Psychology, 24(3), pp. 220-236.

[5] Baltzell, M., 2000. Implications of an ageing population: the changing future profiles of the workforce in international organisations. [online] Available at: $<$ www.alcoa.com.au/news/speeches/BMBFulbrightspeech. html> [Accessed 11 February 2019].

[6] Banihani, M., Lewis, P., Syed, J., 2013. Is work engagement gendered? Gender in Management: An International Journal, 28(7), pp. 400-423.

[7] Beck, V., 2013. Employers use of older workers in the recession. Employee Relations, 35(3), pp. 257-271.

[8] Bejtkovský, J., 2016. The employees of baby boomers generation, generation $\mathrm{X}$, generation $\mathrm{Y}$ and generation $\mathrm{Z}$ in selected Czech corporations as conceivers of development and competitiveness in their corporation. Journal of Competitiveness, 8(4), pp. 105-123.

[9] Brown, S. K., 2005. Attitudes of individuals 50 and older toward phased retirement. Washington: AARP.

[10] Chasteen, A. L., Schwarz, N., Park, D. C., 2002. The activation of aging stereotypes in younger and older adults. The Journals of Gerontology, 57(6), pp. 540-547.

[11] Costello, A. M., Osborne, J. W., 2005. Best practices in exploratory factor analysis: Four recommendations for getting the most from your analysis. Practical Assessment, Research \& Evaluation, 10(7), pp. 1-9.

[12] Davies, E. M. M., Hanley, K., Jenkins, A. K., Chan, C., 2017. Learning and training for older workers. [online] Available at: < https://pure.hud.ac.uk/en/publications/learning-and-tr aining-for-older-workers $>$ [Accessed 11 February 2019].

[13] Dworschak B., Buck, H., Schletz, A., 2006. Building Workplaces in Line With the Ageing Process. In Tikkanen, T., Nyhan, B., 2006. Promoting Lifelong Learning for Older Workers: An International Overview. Luxembourg: Office for Official Publications of the European.

[14] Eurofound. (2015). Working conditions of workers of different ages. [online] Available at: <https://www.eurofou nd.europa.eu/sites/default/files/ef_publication/field_ef_doc ument/ef1747en.pdf > [Accessed 11 February 2019]. 
[15] Field, A., 2013. Discovering statistics using IBM SPSS statistics. London: Sage Publications

[16] Fraccaroli, F., Zaniboni, S., Truxillo, D., 2017. Job design and older workers. Advanced Series in Management, 17, pp. 139-159.

[17] Frith, B., 2017. Financial services have worst mental health. [online] Available at: $<$ https://www.hrmagazine.co.uk/artic le-details/financial-sector-has-worst-mental-health> [Acce ssed 11 February 2019].

[18] Fuertes, V., Egdell, V., McQuaid, R., 2013. Extending working lives: age management in SMEs. Employee Relations, 35(3), pp. 272-293.

[19] Gruman, J. A., Saks, A. M., 2011. Performance management and employee engagement. Human Resource Management Review, 21(2), pp. 123-136.

[20] Haymes, R., 2013. Health, wellbeing and productivity: employers to consider health and wellbeing issues more deeply. Strategic HR Review, 12(5), pp. 1-4.

[21] Hornsby, J. S., Kuratko, D. F., 2003. Human Resource Management in U.S. Small Businesses: A Replication and Extension. Journal of Developmental Entrepreneurship, 8 (1), pp. 73-92.

[22] Humphrey, S. E., Nahrgang, J. D., Morgeson, F. P., 2007. Integrating motivational, social, and contextual work design features: a meta-analytic summary and theoretical extension of the work design literature. Journal of Applied Psychology, 92(5), pp. 1332-1356.

[23] Ilmarinen, J., 2006. Towards a longer worklife! Ageing and the quality of worklife in the European Union. [online] Available at: $<$ www.sopol.at/document/download/towardsa-longer-worklife $>$ [Accessed 11 February 2019].

[24] Ilmarinen, J., 2012. Promoting active ageing in the workplace. [online] Available at: <https://osha.europa.eu/e n/tools-and-publications/publications/articles/promoting-ac tive-ageing-in-the-workplace> [Accessed 11 February 2019].

[25] Kaiser, H. F., 1974. An Index of Factorial Simplicity. Psychometrika, 39(1), pp. 31-36.

[26] Koc-Menard, S., 2009. Flexible work options for older workers. Strategic HR Review, 8(2), pp. 31-36.

[27] Kooij, D., Lange, A., Jansen, P., Dikkers, J., 2008. Older workers' motivation to continueto work: five meanings of age: A conceptual review. Journal of Managerial Psychology, 23 (4), pp.364-394.

[28] Korsakienė, R., Raišienė, A. G., Bužavaitė, M., 2017. Work engagement of older employees: do employee and work-related factors matter? Economics and Sociology, 10(4), pp. 151-161.

[29] Lange, A. H., Taris, T.W., Jansen, P.G.W., Smulders, P., Houtman, I.L.D., Kompier, M.A.J., 2006. Age as a factor in the relation between work and mental health: results from the longitudinal TAS study. [online] Available at: <https:// www.researchgate.net/publication/228622511_Age_as_a_f actor_in_the_relation_between_work_and_mental_health_ Results_of_the_longitudinal_TAS_survey> [Accessed 11 February 2019].

[30] Lu, L., Lu, A. C. C. , Gursoy, D., Neale, N. R., 2016. Work engagement, job satisfaction, and turnover intentions: A comparison between supervisors and line-level employees. International Journal of Contemporary Hospitality Management, 28(4), pp. 737-761.

[31] Macey, W. H., Schneider, B. 2008. The meaning of employee engagement. Industrial and Organizational Psychology, 1(1), pp. 3-30.

[32] Magnavita, N., 2017. Productive aging, work engagement and participation of older workers. A triadic approach to health and safety in the workplace. Epidemiology biostatistics and public health 14(2), pp. 1-8.

[33] Manly, B. F., 2005. Multivariate Statistical Methods - A primer. New York: Chapman \& Hall/CRC.

[34] Moyers, P., Coleman, S. D., 2004. Adaptation of the older worker to occupational challenges. Work, 22(2), pp. 71-78.

[35] Naegele, G., Walker, A., 2006. A guide to good practice in age management, European foundation for the improvement of living and working conditions. [online] Available at: <http://www.eurofound.europa.eu/publicatio ns/htmlfiles/ef05137.htm> [Accessed 11 February 2019].

[36] OECD, 2006. Ageing and employment policies - live longer, work longer. [online] Available at: $<$ http://www.oecd.org/e mployment/livelongerworklonger.htm $>$ [Accessed 11 February 2019].

[37] Principi, A., Fabbietti, P., Lamura, G., 2015. Perceived qualities of older workers and age management in companies: Does the age of HR managers matter? Personnel Review, 44(5), pp. 801-820.

[38] Robertson, I. T, Cooper, C. L., 2010. Full engagement: the integration of employee engagement and psychological well-being. Leadership \& Organization Development Journal, 31(4), pp. 324-336.

[39] Rumbles, S., Rees G., 2013. Continuous changes, organizational burnout and the implications for HRD. Industrial and Commercial Training, 45(4), pp. 236-242.

[40] Rune, H. C., Stene, H. P., 2006. High stress levels in financial services and insurance sector. [online] Available at: <https://www.eurofound.europa.eu/publications/article/ 2006/high-stress-levels-in-financial-services-and-insurance -sector> [Accessed 11 February 2019].

[41] Sanyal, C., Wilson, D., Sweeney, C., Smith Rachele, J., Kaur, S., Yates, C., 2015. Diversity and inclusion depend on effective engagement: It is everyone's business to ensure that progress is maintained. Human Resource Management International Digest, 23 (5), pp. 21-24.

[42] Slattery, J. P., Selvarajan, T. T., Anderson, J. E., Sardessai, R., 2010. Relationship between job characteristics and attitudes: a study of temporary employees. Journal of Applied Social Psychology, 40(6), pp. 1539-1565.

[43] Spencer, S., 2018. Is age discrimination a problem in financial services? [online] Available at: <https://www.bar claysimpson.com/blogs/is-age-discrimination-a-problem-in -financial-services-81071797591> [Accessed 11 February 2019].

[44] Tew, M. (2004). The ageing worker. Ontario: Occupational Health Clinics for Ontario Workers Inc. 
[45] Truxillo, D. M., Cadiz, D. M., Rineer, J. R., Zaniboni, S., Fraccaroli, F., 2012. A lifespan perspective on job design: fitting the worker to the job to promote job satisfaction, engagement, and performance. Organizational Psychology Review, 2(4), pp. 340-360.

[46] Vasconcelos, A. F., 2015. Older workers: some critical societal and organizational challenges. Journal of Management Development, 34(3), pp. 352-372.

[47] Wade, H. K., 2003. Marketing the workplace to older workers: determinants of employer choice among mature employees. Florida: Argosy University.

[48] Wagner, R., Harter, J. K., 2006. 12: The Elements of Great Managing. New York: Gallup Press.

[49] Warr, P., Fay, D., 2001. Age and personal initiative at work. European Journal of Work and Organizational Psychology, 10 , pp. 343-353.

[50] Xu, J., Thomas, H.C., 2011. How can leaders achieve high employee engagement? Leadership \& Organization Development Journal, 32(4), pp. 399-416.

[51] Zacher, H., Rudolph, C. W., 2017. Successful aging at work and beyond: A review and critical perspective. Age diversity in the workplace. 4(2), pp.35-64.

[52] Zaniboni, S., Truxillo, D. M., Fraccaroli, F., McCune, E. A., Bertolino, M., 2014. Who benefits from more tasks? Older versus younger workers. Journal of Managerial Psychology, 29 (5), pp. 508-523. 